\title{
АНАЛИЗ ЭФФЕКТОВ СОВМЕСТНОЙ ИНОКУЛЯЦИИ ГРИБАМИ АРБУСКУЛЯРНОЙ МИКОРИЗЫ И РИЗОБИЯМИ НА РОСТ И РАЗВИТИЕ РАСТЕНИЙ ГОРОХА Pisum sativum L.*
}

\author{
И.В. ЛЕППЯНЕН, О.Ю. ШТАРК, О.А. ПАВЛОВА, А.Д. БОВИН,

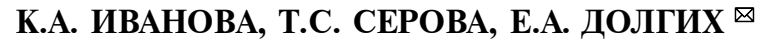

\begin{abstract}
Совместная инокуляция грибами арбускулярной микоризы и азотфиксирующими бактериями порядка Rhizobiales (ризобиями) способна стимулировать рост и развитие растений. Такое влияние может быть как проявлением синергического эффекта двух микроорганизмов на растение в многокомпонентной системе, так и результатом взаимного воздействия микроорганизмов друг на друга, однако механизмы, которые лежат в основе взаимного влияния микроорганизмов, остаются недостаточно полно изученными. В представленной работе впервые показано, что при совместной инокуляции растений гороха грибами арбускулярной микоризы и ризобиями важен способ внесения микроорганизмов. При последовательной инокуляции наблюдалась конкуренция микроорганизмов за нишу в растении. Нашей целью было изучение возможности использования комбинации штаммов грибов арбускулярной микоризы Rhizophagus irregularis BEG144 и ризобий Rhizobium leguminosarum bv. viciae RCAM 1026 для совместной инокуляции гороха посевного Pisum sativum L. У растений оценивали индукцию маркеров развития двух типов симбиоза, степень микоризации корней, а также биометрические показатели. Исследования проводили на проростках гороха copтa Frisson, выращенных в стерильных условиях. Для инокуляции использовали изолят гриба Rhizophagus irregularis BEG144. Получали инокулюм на основе микоризованных корней плектрантуса (Plecthrantus australis). Инокулюм вносили в увлажненный субстрат перед посадкой проростков гороха. Через 7 сут после посадки в систему вносили штамм ризобий Rhizobium leguminosarum bv. viciae RCAM 1026. Схема опыта включала следующие варианты: без инокуляции (контроль), R. leguminosarum (Rlv), R. irregularis (AM), R. irregularis + R. leguminosarum (AM + Rlv). Через 9 и 21 сут после посадки (через 2 и 14 сут после бактериальной инокуляции) собирали материал для анализа экспрессии генов - маркеров развития бобово-ризобиального симбиоза. На 21-е сут после посадки проводили сбор растений с целью определения их биометрических параметров, а также контроля развития симбиозов. Боковые корни обрезали и замораживали в жидком азоте. После выделения суммарной РНК синтезировали кДНК на матрице РНК с помощью обратной транскриптазы с использованием олиго(дТ) праймеров и проводили анализ методом количественной ПЦР, совмещенной с обратной транскрипцией (ОТ-ПЦР) (CFX96 Real-Time, «Bio-Rad Laboratories», CША). Было показано, что общая масса растений и масса корневой системы достоверно $($ p $<0,05)$ повышались при инокуляции Rlv, AM и AM+ Rlv по сравнению с контрольным вариантом. Однако достоверных различий по этим биометрическим показателям между вариантом с Rlv или AM и двойной инокуляцией выявлено не было. Вероятно, при последовательной инокуляции несколькими эндосимбионтами между ними возникала конкуренция на стадии проникновения в растение, что приводило к уменышению интенсивности инфекции растений ризобиями. Об этом свидетельствовал тот факт, что при двойной инокуляции отсутствовала дополнительная стимуляция экспрессии генов Enod5 и $\operatorname{Sym} 37$, которые активируются у растения в процессе развития ризобиальной инфекции. При двойной инокуляции мы также не выявили дополнительной стимуляции экспрессии маркерных генов симбиоза с грибами АM - PT4, TI, RAM1 и DELLA3. Полученные данные не позволяют сделать вывод о положительном влиянии двойной инокуляции на рост и развитие растений гороха при использованной схеме внесения микроорганизмов. Результаты могут указывать на наличие конкуренции микроорганизмов за нишу в растении, приводящей к снижению внутрикорневой микоризной колонизации и степени индукции маркеров, которые активируются в процессе развития ризобиальной инфекции.
\end{abstract}

Ключевые слова: растительно-микробные взаимодействия, ризосфера, симбиоз, арбускулярная микориза, ризобии, Rhizophagus irregularis, экспрессия генов, Pisum sativum.

В настоящее время перед сельским хозяйством стоит проблема перехода от интенсивного типа к устойчивому, направленному на производство экологически чистой продукции $(1,2)$. В результате должно снизиться применение минеральных удобрений, активное использование которых требует значительных финансовых затрат и наносит ущерб окружающей среде (3). Существенную роль в улучшении минерального питания растений,

\footnotetext{
* Исследования выполнены при финансовой поддержке РНФ (грант № 17-76-30016).
} 
прежде всего фосфорного, и повышении их продуктивности играет способность большинства сельскохозяйственных культур формировать эндосимбиозы с микоризными грибами филы Glomeromycota (арбускулярная микориза, АМ). Альтернативой применению минеральных азотных удобрений может стать использование биологического азота. Значительную роль в биологической фиксации азота играют симбиозы между бобовыми растениями и бактериями порядка Rhizobiales, называемыми ризобиями.

Совместная инокуляция грибами АМ и ризобиями также оказывает положительный эффект на растения, главным образом благодаря улучшению минерального питания и ингибированию развития грибных патогенов (4-7). Поскольку недостаток фосфора и азота в почве служит одним из лимитирующих факторов при развитии растений, совместная инокуляция стимулирует их рост. При этом стимулирующее влияние может быть как проявлением синергического эффекта микроорганизмов в отношении растения в многокомпонентной системе, так и результатом воздействия микроорганизмов друг на друга. Однако механизмы, которые лежат в основе взаимного влияния микроорганизмов, остаются недостаточно изученными.

Известно, что грибы АМ обеспечивают растения доступным фосфором, который играет важную роль в энергетическом обмене и особенно в таком энергозатратном процессе, как азотфиксация (8). Мобилизация фосфора может стимулировать активность нитрогеназы и азотфиксацию, осуществляемую ризобиями (9-11). Действительно, при совместной инокуляции фасоли Phaseolus vulgaris L. и люцерны Medicago arborea L. грибами AM и ризобиями наблюдали значительное увеличение числа и массы клубеньков по сравнению с растениями при моноинокуляции $(12,13)$. Это приводило к большему накоплению фосфора и азота в побегах фасоли и улучшению эффективности использования фосфора по сравнению с контрольными растениями (12). Положительное влияние двойной инокуляции грибами АМ и ризобиями на рост, поглощение питательных веществ и фиксацию азота выявлено у сои (4), вигны (14) и гороха (15). Показано, что двойная инокуляция растений гороха приводит к увеличению их биомассы, числа и биомассы клубеньков, а также эффективности азотфиксации и транспорта связанных форм азота $(16,17)$.

Взаимное влияние может быть обусловлено сигнальными молекулами, которыми обмениваются грибы АМ и ризобии с растением - Муси Nod-факторами. Совместная инокуляция сои Glycine max (L.) Merr. штаммом Bradyrbizobium japonicum 61-A-101 значительно усиливала колонизацию корней растений грибом Glomus mosseae (18). Было установлено, что на стимуляцию развития микоризы могут влиять Nod-факторы ризобий, поскольку инокуляция растений штаммами, дефектными по синтезу этих сигнальных соединений, не приводила к увеличению колонизации корней грибом. Положительный эффект может быть связан со структурным сходством Nod- и Мус-факторов, так как последние представляют собой базовую структуру Nod-фактора с минимальными заместителями на остове молекулы (19). Кроме того, Nod-факторы активируют синтез флавоноидов в корнях растений, которые также оказывают стимулирующий эффект на колонизацию корней грибами АМ (18).

Совместная инокуляция влияет и на увеличение устойчивости к патогенам. Известно, что у растений, инокулированных грибами АМ, снижается заболеваемость и степень выраженности симптомов, вызываемых Rhizoctonia, Fusarium или Verticillium, а также оомицетами Phytophthora, Pythium и Aphanomyces (20). Вместе с тем биоконтрольные свойства ризобий могут быть связаны с выделением литических ферментов и антимикробных 
вторичных метаболитов, подавляющих развитие патогенов (21). При совместной инокуляции действие грибов АМ и ризобий может усиливаться. Так, у сои проявление признаков развития красной коронной гнили было значительно снижено при двойной инокуляции, что коррелировало с высокой экспрессией генов PR2, PR3, PR4 и PR10, контролирующих защитные реакции (22). При этом остается неясным, как грибы АМ и ризобии в многокомпонентной системе избегают взаимного негативного влияния, вызванного выделением литических ферментов и антимикробных соединений.

Вероятно, из-за особенностей взаимного влияния воздействие грибов АМ и ризобий на растение при совместной инокуляции сильно варьирует в зависимости от штаммов, которые были использованы. При этом может наблюдаться как значительная стимуляция роста растений, так и отсутствие выраженного эффекта $(15,23)$. Например, урожайность и содержание азота у растений гороха были максимальными при совместной инокуляции грибом Glomus clarum NT4 и высокоэффективным штаммом Rhizobium LX43 (15). Напротив, штамм другого вида грибов Glomus mossae NT6 увеличивал урожайность гороха при совместной инокуляции только с малоэффективным штаммом ризобий $175 \mathrm{P} 4$ (15). Следовательно, посредством подбора эффективных комбинаций штаммов грибов и ризобий можно влиять на урожайность сельскохозяйственных культур, однако необходимо понимать, какие механизмы лежат в основе такого взаимодействия.

В представленной работе впервые показано, что при совместной инокуляции растений гороха грибами арбускулярной микоризы и ризобиями важен способ внесения микроорганизмов. При последовательной инокуляции наблюдалась конкуренция микроорганизмов за нишу в растении.

Нашей целью было изучение возможности использования комбинации штаммов грибов арбускулярной микоризы Rhizophagus irregularis BEG144 и ризобий Rhizobium leguminosarum bv. viciae RCAM 1026 для инокуляции гороха посевного Pisum sativum L., оценка индукции маркеров развития двух типов симбиоза, степени микоризации корней, а также биометрических показателей растений.

Методика. В экспериментах использовали проростки гороха сорта Frisson, выращенные в стерильных условиях. Семена стерилизовали концентрированной $\mathrm{H}_{2} \mathrm{SO}_{4}$ в течение 10 мин, затем 3-кратно промывали стерильной дистиллированной водой и проращивали в чашках Петри с $1 \%$ агаром в течение 4 сут при комнатной температуре в темноте.

Инокулюм изолята гриба Rhizophagus irregularis BEG144, предоставленного Международным банком Glomeromycota (The International Bank for the Glomeromycota, г. Жидон, Франция) получали на основе микоризованных корней плектрантуса (Plectranthus australis). Корни плектрантуса промывали в проточной водопроводной воде, ополаскивали 3 раза дистиллированной водой и нарезали на фрагменты длиной около 1 см. Сырые корни просматривали под микроскопом, чтобы контролировать присутствие пропагул гриба - везикул и спор. Инокулюм (1,3 г на горшок) вносили в увлажненный субстрат на глубину 3 см перед посадкой проростков гороха. Через 7 сут после посадки в систему вносили штамм ризобий Rhizobium leguminosarum bv. viciae RCAM 1026. Бактерии выращивали при $28{ }^{\circ} \mathrm{C}$ на твердой среде TY (24), содержащей антибиотик стрептомицин в концентрации 500 мкг/мл. Бактерии смывали с чашек автоклавированной водопроводной водой. Полученную суспензию разводили до оптической плотности $\mathrm{OD} 600=0,5$. Для инокуляции одного растения использовали 2 мл ризобиальной суспензии.

Растения выращивали в контролируемых условиях фитотрона MLR- 
352H («Panasonic», Япония) в режиме 16 ч день/8 ч ночь при $21{ }^{\circ} \mathrm{C}$ и относительной влажности $60 \%$. Субстратом служила опока с добавлением $\mathrm{CaCO}_{3}$ (1 г/л). Предварительно вегетационные сосуды с субстратом стерилизовали автоклавированием в течение 60 мин при $134{ }^{\circ} \mathrm{C}$ и $0,22 \mathrm{MПа.}$ Растения подкармливали специально разработанным питательным раствором без фосфора и с пониженным содержанием азота. В состав раствора входили макроэлементы (ммоль л$^{-1}$ субстрата) $\mathrm{NH}_{4} \mathrm{NO}_{3}-0,16(1 / 10$ нормы), $\mathrm{MgSO}_{4} \cdot 7 \mathrm{H}_{2} \mathrm{O}-0,51, \mathrm{~K}_{2} \mathrm{SO}_{4}-0,72$, а также микроэлементы (мкмоль) $\mathrm{H}_{3} \mathrm{BO}_{3}-9,19, \mathrm{MnSO}_{4} \cdot 5 \mathrm{H}_{2} \mathrm{O}-2,28, \mathrm{ZnSO}_{4} \cdot 7 \mathrm{H}_{2} \mathrm{O}-0,19, \mathrm{CuSO}_{4} \cdot 5 \mathrm{H}_{2} \mathrm{O}-$ $0,08,\left(\mathrm{NH}_{4}\right)_{2} \mathrm{MoO}_{4}-0,03, \mathrm{CoCl}_{2} \cdot 6 \mathrm{H}_{2} \mathrm{O}-0,03$, NaFe-EDTA $-8,36$. Подкормку проводили один раз во время посадки проростков гороха, полив осуществляли дистиллированной водой по необходимости.

Схема опыта включала следующие варианты: без инокуляции (контроль), Rhizobium leguminosarum bv. viciae RCAM 1026 (Rlv), Rhizophagus irregularis BEG144 (AM), R. irregularis $+R$. leguminosarum (AM+ Rlv).

Через 9 и 21 сут после посадки (через 2 и 14 сут после бактериальной инокуляции) собирали материал для анализа экспрессии маркеров развития бобово-ризобиального симбиоза (гены Sym 10, NIN, Enod5 и Sym37). Ha 21е сут после посадки (14-е сут после инокуляции ризобиями) проводили сбор растений с целью определения их биометрических параметров и анализа экспрессии маркеров инокуляции грибом АM (гены PT4, TI, RAM1 и $D E L L A 3)$, а также контроля развития симбиозов. Развитие АМ оценивали с использованием световой микроскопии по методике, описанной ранее (25).

Боковые корни растений обрезали и замораживали в жидком азоте. Суммарную РНК выделяли из них с помощью колонок NucleoSpin ${ }^{\circledR}$ RNA по методике производителя («Macherey-Nagel», ФРГ). Синтез кДНК на матрице РНК проводили с помощью обратной транскриптазы RevertAidH minus («Thermo Scientific», США) с использованием олиго(дТ) праймеров («Евроген», Россия). Для анализа применяли количественную ПЦР, совмещенную с обратной транскрипцией (ОТ-ПЦР) (прибор CFX96 Real-Time, «Bio-Rad Laboratories», США) в следующих условиях: 30 с при $95{ }^{\circ} \mathrm{C}, 30$ с при $54{ }^{\circ} \mathrm{C}, 40$ с при $72{ }^{\circ} \mathrm{C}$ (40 циклов). Для проведения ПЦР использовали следующие праймеры:
PsSym 10-F - 5'-GTACTTCATTGGCGGAGACTG-3';
Ps Sym 10-R- 5'-CCATAAGTTTCACAAGATTTCCAT-3';
PSNIN-F - 5'-CCGCAAAGAGCATCGGTGTATG-3';
PSNIN-R - 5'-GCATAGAAAGATCCAATCTGTATAGC-3';
PSPT4-F - 5'-CTTCACGTGCCATGTTCATC-3';
PsPT4-R - 5'-GCGTCGGAAACAGCTCC-3';
PSTI-F - 5'-ACCTTACAGCGTGAGCCTATAAGA-3';
PsTI-R - 5'-GCGGCCGAGGTACGAAAGGTG-3';
PsRAM1-F - 5'-GTCCATGATAAGAGACCAAGCACC-3';
PsRAM1-R - 5'-GGAGGAAGATAATGGAAGGGAAAG-3';
PSDELLA3-F - 5'-GCAATATAGAATTAACCGCCACAAC-3';
PSDELLA3-R - 5' -CGGATGAGCGGGACAACC-3'.

Количество мРНК было нормализовано относительно двух конститутивно экспрессируемых генов, кодирующих убиквитин и актин. Были проанализированы 3 независимые биологические повторности.

Статистическую обработку результатов проводили в программе SigmaPlot 12,0 («SPSS Inc.», США). Рассчитывали средние $(M)$ и стандартные ошибки средних $( \pm \mathrm{SEM})$. Для оценки значимости различий между вариантами использовали однофакторный дисперсионный анализ (One-Way ANOVA) с множественными попарными сравнениями при помощи post hoc 
теста Тьюки (ANOVA post hoc test). Различия считали статистически значимыми при $\mathrm{p}<0,05$.

Результаты. В качестве маркеров развития ранних симбиотических реакций у растений гороха при инокуляции ризобиями были выбраны гены Sym 10 и NIN, которые активируются в корнях растений на 1-2-е сут в ответ на инокуляцию (26). Ген Sym 10 кодирует LysM-содержащую рецептор-подобную киназу, которая вовлечена в узнавание сигнальных молекул ризобий - липохитоолигосахаридов Nod-факторов. Активация сигнального каскада под влиянием рецептора SYM10 приводит к развитию на корнях растений азотфиксирующих клубеньков. В процессе передачи сигнала у растений существенно возрастает экспрессия гена NIN (Nodule Inception, возникновение клубеньков), который кодирует транскрипционный фактор и таким образом участвует в инициации развития симбиоза гороха с ризобиями.

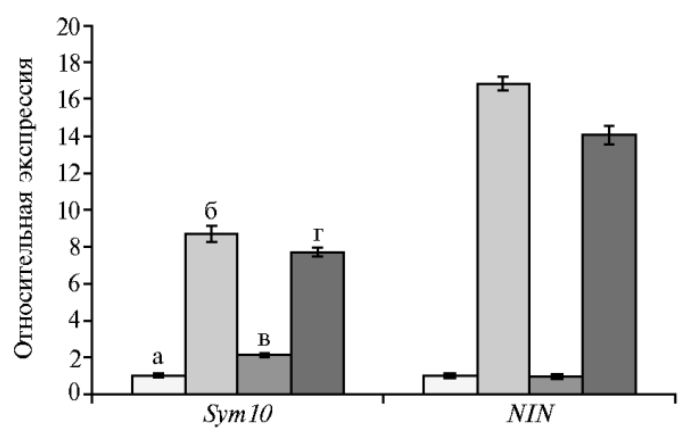

Рис. 1. Экспрессия генов Sym 10 (ген рецептора сигнальных молекул ризобий) и $N I N$ (ген основного транскрипционного фактора сигнального пути) в корнях гороха Pisum sativum L. сорта Frisson через 9 сут после посадки растений в субстрат, содержащий Rhizophagus irregularis BEG144, и через 2 сут после инокуляции Rhizobium leguminosarum bv. viciae RCAM 1026: а - без инокуляции (контроль), б - R. leguminosarum, в $-R$. irregularis, $\Gamma-R$. irregularis $+R$. leguminosarum. Бары представляют стандартные ошибки среднего ( $\pm \mathrm{SEM})$ для трех технических повторностей. Были проанализированы три биологические повторности; представлены результаты для одной из них.

В вариантах опыта с моноинокуляцией ризобиями наблюдалось значительное увеличение экспрессии генов $S y m 10$ и $N I N$ по сравнению с неинокулированным контролем на 9-е сут (рис. 1). У растений, инокулированных грибами АМ $R$. irregularis BEG144, не было выявлено существенных изменений в экспрессии Sym 10 и NIN, что свидетельствует о специфичном характере активации этих генов только в ответ на узнавание сигнальных молекул ризобий (см. рис. 1). При этом экспрессия Sym 10 и NIN оставалась высокой при совместной инокуляции Rlv и грибами AM (см. рис. 1). На наш взгляд, это свидетельствует, о том, что на начальных этапах становления и развития многокомпонентной системы растение эффективно различает сигналы ризобий. Они стимулируют развитие у растения ранних ответных реакций, включающих изменение потоков ионов через плазматическую мембрану и ее деполяризацию, образование активных форм кислорода и активацию каналов, регулирующих поступление кальция в клетки растений $\left(\mathrm{Ca}^{2+}\right.$ influx).

В качестве маркеров развития симбиоза с грибами АМ были использованы гены PT4, TI, RAM1 и DELLA3, экспрессия которых наиболее существенно увеличивается на 21-28-е сут после инокуляции грибами АМ (27). Ген PT4 кодирует переносчик фосфата (17), активация которого связана с более поздними стадиями развития симбиоза с грибами АМ, когда формируются арбускулы и везикулы. Ингибитор транскрипции, кодируемый геном $T I$ (17), выявлен при изучении транскриптомных профилей корней гороха, инокулированного грибом АМ. Среди транскрипционных факторов, экспрессия которых увеличивается при развитии симбиоза с грибами АМ, ранее был обнаружен регулятор RAM1 (27). Белки DELLA - регуляторы ответа растений на гиббереллины, они принимают непосредственное участие в контроле развития как азотфиксирующего симбиоза, так и симбиоза 
с грибами АМ $(28,29)$. Белки взаимодействуют с основными транскрипционными факторами сигнальных путей - NSP2, IPD3 и RAM1, что стимулирует активацию генов-мишеней (29). Ранее мы показали, что у растений гороха при симбиозе с грибами АМ увеличивается экспрессия одного из генов этого семейства $-D E L L A 3$ (27).

В наших опытах на 21-е сут после посадки было выявлено значительное увеличение экспрессии генов PT4 и $T I$ в варианте с моноинокуляцией грибами $R$. irregularis BEG144, а также в варианте с двойной инокуляцией $(\mathrm{AM}+\mathrm{Rlv})$ (рис. 2). Сходным образом экспрессия генов RAM1 и $D E L L A 3$ увеличивалась в вариантах с AM и AM + Rlv. Это свидетельствовало о способности растений отвечать на инокуляцию грибами АМ при совместном внесении с ризобиями, однако дополнительной стимуляции экспрессии маркерных генов при двойной инокуляции выявлено не было.

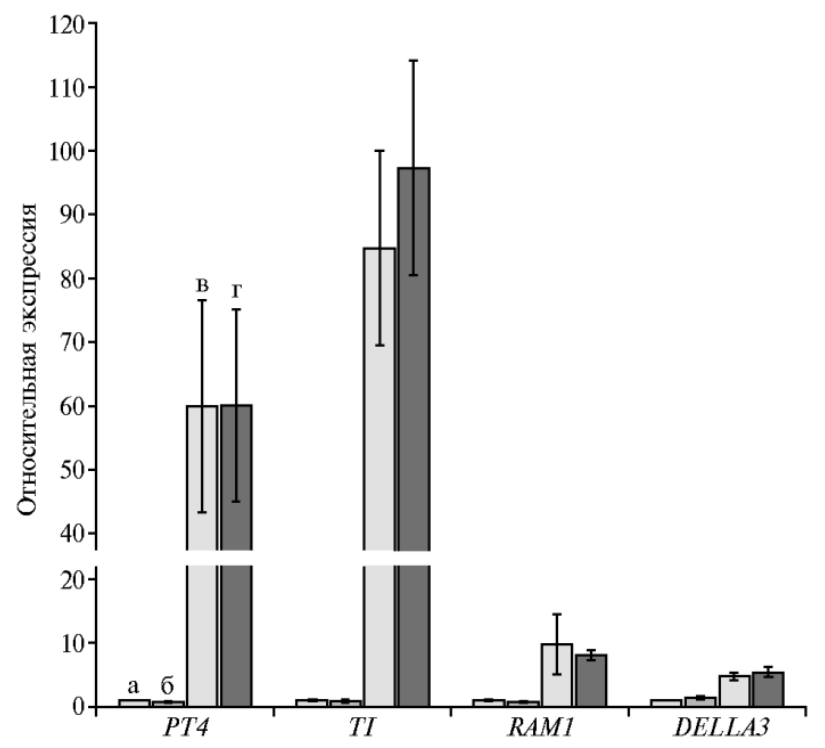

\begin{abstract}
Рис. 2. Экспрессия генов переносчика фосфата PT4, ингибитора транскрипции $T I$, транскрипционного фактора $R A M 1$ и регулятора ответа растений на гиббереллины $D E L L A 3$ в корнях гороха Pisum sativum L. сорта Frisson через 21 сут после посадки растений в субстрат, содержащий Rhizophagus irregularis BEG144, и через 14 сут после инокуляции Rhizobium leguminosarum bv. viciae RCAM 1026: a - без инокуляции (контроль), б $-R$. leguminosarum, в $-R$. irregularis, $\Gamma-R$. irregularis $+R$. leguminosarum. Бары представляют стандартные ошибки среднего ( \pm SEM) для трех технических повторностей. Были проанализированы три биологические повторности и представлены результаты для одной из них.
\end{abstract}

На 21-е сут мы также проанализировали экспрессию генов, которые могут активироваться в процессе развития инфекции при бобово-ризобиальном симбиозе у гороха - Enod5 и Sym37. Enod5 кодирует нодулин, активирующийся специфичным образом в клетках корней гороха, в которые проникают инфекционные нити $(30,31)$. Ген Sym37 кодирует рецептор, который необходим для развития и распространения инфекционных нитей у гороха (32).

Экспрессия генов Enod5 и Sym37, как и Sym10 и NIN, возрастала в варианте с моноинокуляцией ризобиями на 21-е сут после посадки (рис. 3). Изменений в экспрессии этих генов при инокуляции грибами $R$. irregularis BEG144 выявлено не было (см. рис. 3). В варианте AM + Rlv наблюдали увеличение экспрессии гена NIN по сравнению с моноинокуляцией Rlv. Однако экспрессия выбранных для анализа генов Enod5 и $S y m 37$, связанных с контролем развития инфекции, при двойной инокуляции оставалась сходной с аналогичным показателем при моноинокуляции ризобиями. Экспрессия Sym 10 также существенно не изменялась при совместной инокуляции растений гороха грибами и ризобиями.

Развитие инфекционного процесса при бобово-ризобиальном симбиозе и симбиозе с грибами АМ находится под контролем растения-хозяина. Вероятно, при последовательной инокуляции несколькими эндосимбионтами между ними возникает конкуренция на стадии проникновения в 
растение, что приводит к уменьшению интенсивности инфекции ризобиями. Об этом, на наш взгляд, свидетельствует тот факт, что при двойной инокуляции отсутствует дополнительная стимуляция экспрессии генов Enod5 и Sym37, которые активируются в процессе развития ризобиальной инфекции.

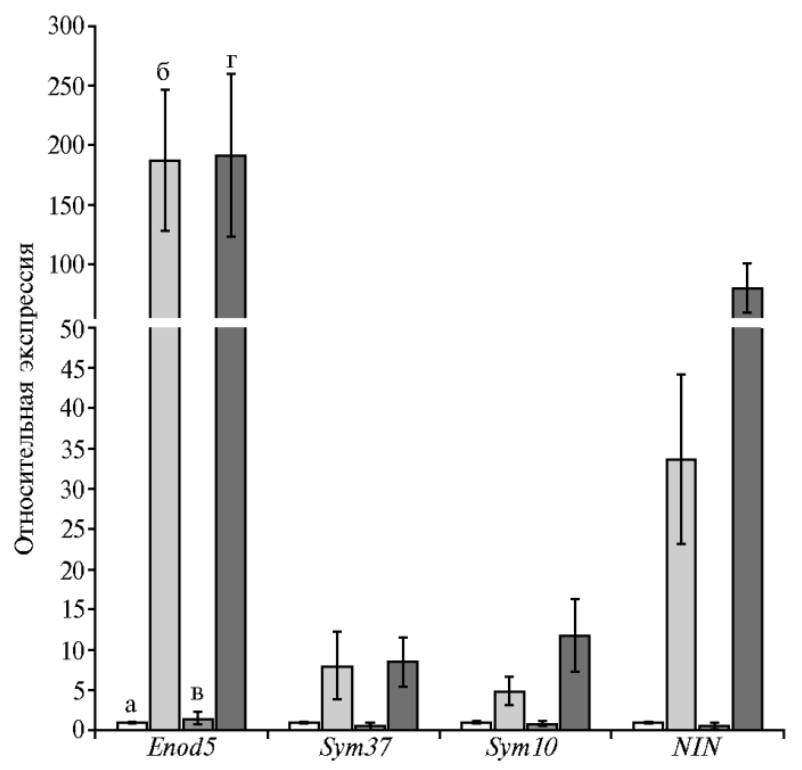

Рис. 3. Экспрессия генов Enod5 и Sym37, которые могут активироваться в процессе развития инфекционного процесса при бобово-ризобиальном симбиозе, в корнях гороха Pisum sativum L. сорта Frisson через 21 сут после посадки растений в субстрат, содержащий Rhizophagus irregularis BEG144, и через 14 сут после инокуляции Rhizobium leguminosarum bv. viciae RCAM 1026: а - без инокуляции (контроль), б - R. leguminosarum, в $-R$. irregularis, $\Gamma-R$. irregularis $+R$. leguminosarum. Бары представляют стандартные ошибки среднего ( \pm SEM) для трех технических повторностей. Были проанализированы три биологические повторности и представлены peзультаты для одной из них.

В варианте с моноинокуляцией Rlv наблюдали выраженную тенденцию к увеличению общей биомассы растений по сравнению с аналогичным показателем в контроле ( $\mathrm{p}=0,072)$ (рис. 4).
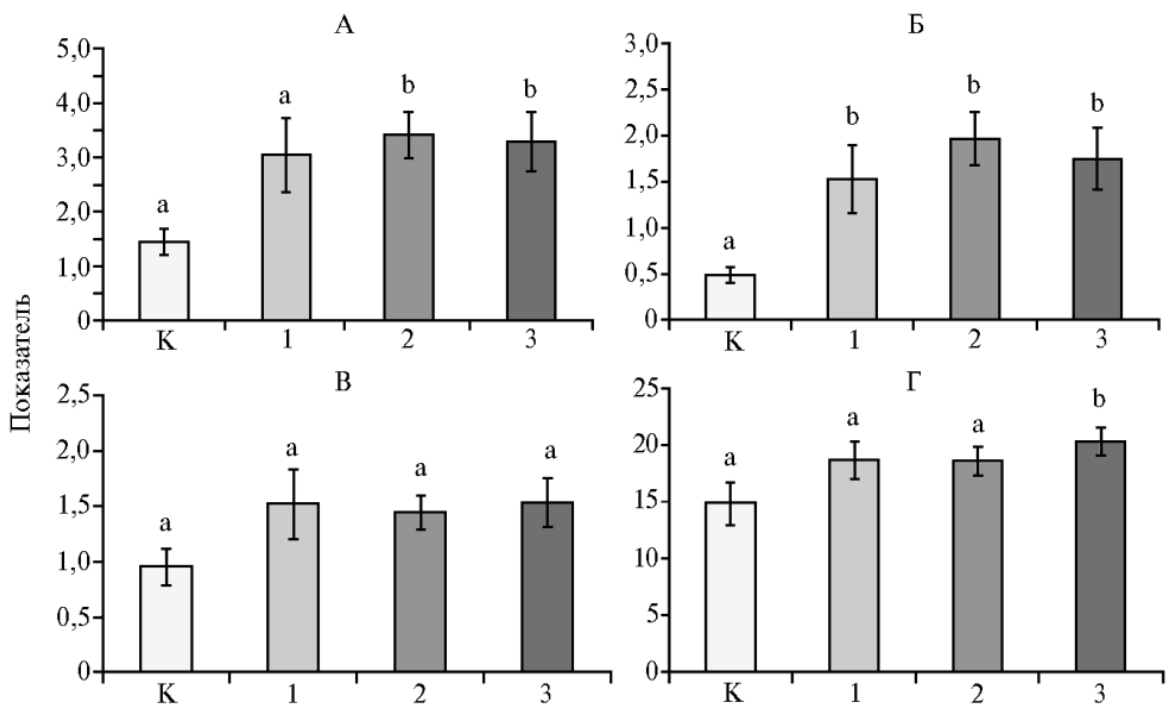

Рис. 4. Общая биомасса, г (А), масса корней, г (Б), масса надземной части, г (В) и длина корней, см (Г) у гороха Pisum sativum L. сорта Frisson через 21 сут после посадки растений в субстрат, содержащий Rhizophagus irregularis BEG144, и через 14 сут после инокуляции Rhizobium leguminosarum bv. viciae RCAM 1026: $\mathrm{K}$ - без инокуляции (контроль), $1-R$. leguminosarum, $2-$ $R$. irregularis, $3-R$. irregularis $+R$. leguminosarum. Представлены средние арифметические значения для $n=12-15$. Бары - стандартные ошибки среднего ( $\pm \mathrm{SEM})$. Статистически значимо различающиеся варианты обозначены разными буквами $(\mathrm{p}<0,05)$. Для оценки значимости различий между вариантами использовали однофакторный дисперсионный анализ с post hoc тестом Тьюки (One-Way ANOVA post hoc test). 
При этом в случае моноинокуляции грибами АМ было выявлено достоверное изменение $(\mathrm{p}<0,05)$ общей биомассы растений, как и в варианте с совместной инокуляцией $(\mathrm{p}<0,05)$ (см. рис. 4 , А). Масса корневой системы достоверно (p < 0,05) повышалась при инокуляции Rlv, AM и $\mathrm{AM}+\mathrm{Rlv}$ по сравнению с контролем. В то же время между всеми тремя вариантами инокуляции не наблюдалось достоверных различий по этому показателю (см. рис. 4, Б). При анализе биомассы надземной части не было выявлено достоверных различий между контролем и вариантами с моноинокуляцией Rlv и AM, а также при совместной инокуляции AM + Rlv (см. рис. 4, В).

При инокуляции Rlv и AM наблюдалась тенденция к увеличению длины корня растений по сравнению с контролем (соответственно $\mathrm{p}=0,08$ и $\mathrm{p}=0,09)$, однако только в случае совместной инокуляции это увеличение было достоверным (p < 0,05) (см. рис. 4, Г). Существенного влияния на длину надземной части не выявили ни в одном варианте инокуляции.

На основании полученных результатов можно сделать вывод о том, что в условиях нашего эксперимента моноинокуляция ризобиями и грибами AM была эффективной. Моноинокуляция Rlv и грибами АМ положительно влияла главным образом на увеличение массы корневой системы, но не надземной части. При двойной инокуляции наблюдали небольшое увеличение длины корней растений. Однако отсутствие достоверных различий по таким биометрическим показателям, как масса растения и масса корня, между вариантом с моноинокуляцией Rlv или AM и двойной инокуляцией не позволяет сделать вывод о положительном влиянии двойной инокуляции на рост и развитие растений гороха.

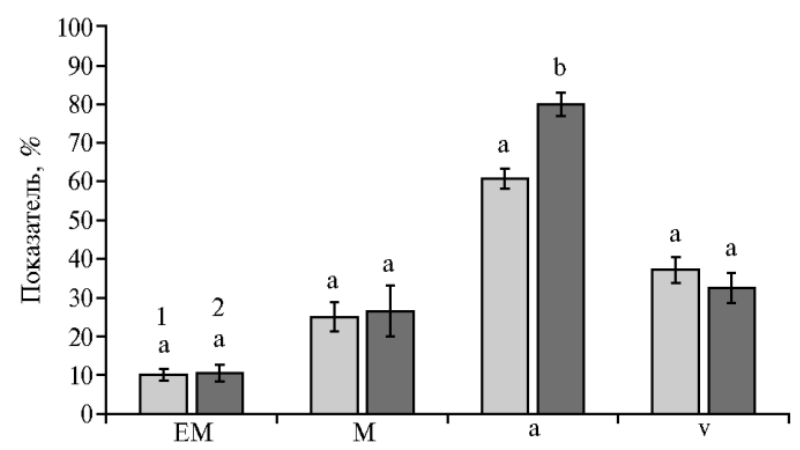

Рис. 5. Параметры развития арбускулярной микоризы у гороха $\mathrm{Pi}$ sum sativum L. сорта Frisson через 21 сут после посадки растений в субстрат, содержащий Rhizophagus irregularis BEG144, и через 14 сут после инокуляции Rhizobium leguminosarum bv. viciae RCAM 1026: EM - интенсивность внешней колонизации, М - интенсивность внутрикорневой колонизации, а содержание арбускул в микоризованных фрагментах корней, v содержание везикул в микоризованных фрагментах корней; 1 $R$. irregularis, $2-R$. irregularis $+R$. leguminosarum. Представлены средние арифметические значения для $n=12-15$. Бары - стандартные ошибки среднего ( $\pm \mathrm{SEM})$. Статистически значимо различающиеся варианты обозначены разными буквами $(\mathrm{p}<0,05)$. Для оценки значимости различий между вариантами использовали однофакторный дисперсионный анализ c post hoc тестом Тьюки (One-Way ANOVA post hoc test).

Анализ развития симбиотических систем на 21-е сут после посадки показал, что все растения, инокулированные ризобиями, образовали розо-

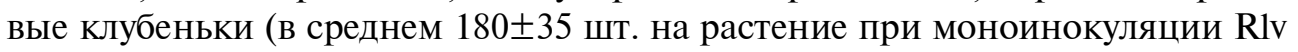
и 228土55 шт. при AM + Rlv). Статистически достоверных различий по числу клубеньков между этими двумя вариантами не наблюдалось.

В обоих вариантах с инокуляцией грибами (AM и AM + Rlv) растения имели примерно одинаковую интенсивность внешней колонизации корней (ЕМ\%) гифами R. irregularis (около 10 \%) (рис. 5). Это свидетельствовало о хорошем качестве микоризного инокулюма. Внутрикорневой мицелий развивался довольно интенсивно в обоих вариантах, однако между 
вариантами не наблюдалось достоверных различий в интенсивности внутрикорневой колонизации (М\%) (см. рис. 5). В микоризованных отрезках корней отмечали интенсивное развитие арбускул. При этом относительное содержание арбускул (а\%) в варианте с двойной инокуляцией было достоверно выше $(\mathrm{p}<0,05)$, чем в варианте с моноинокуляцией грибами АМ, что свидетельствует о более интенсивном обмене питательными веществами между грибными и растительными клетками (см. рис. 5). Инокуляция ризобиями не повлияла на относительное содержание везикул (v\%), служащих запасающими органами грибов АМ (см. рис. 5). В вариантах без инокуляции грибами (контроль и инокуляция Rlv) не было обнаружено структур грибов АМ, что свидетельствует об отсутствии перекрестной контаминации этими микроорганизмами.

В целом на основании проведенного анализа можно сделать вывод о том, что бобово-ризобиальный симбиоз и симбиоз с грибами АМ развивались в изучаемой нами системе. В связи с этим полученные данные по экспрессии генов - маркеров симбиозов можно считать адекватными. Однако анализ развития двойного симбиоза показал, что при использовании комбинации AM + Rlv в случае последовательной инокуляции не наблюдается достоверного увеличения внутрикорневой микоризной колонизации, что, вероятно, определяется конкуренцией микроорганизмов за нишу в растении или стимуляцией системного ответа со стороны растений.

Анализ данных литературы показывает, что грибы АМ и ризобии могут действовать синергически, стимулируя рост растений посредством улучшения минерального питания и ингибирования развития грибных патогенов (4-7). Вместе с тем в нескольких работах было установлено, что конкуренция за нишу в растении может быть причиной снижения эффективности колонизации корней грибами АМ. Так, исследования на сое Glycine max (L.) Merrill по изучению потенциала коммерческого инокулюма грибов AM Glomus sp. R-10 в отношении повышения урожайности этой сельскохозяйственной культуры выявили негативное влияние на колонизацию корней эндогенных штаммов грибов, хорошо адаптированных к условиям выращивания растений (33). Сходным образом конкуренция за нишу в растении была причиной снижения внутрикорневой колонизации культивируемых in vitro корней моркови при совместной инокуляции грибами АМ Rhizophagus irregularis и Glomus aggregatum по сравнению с моноинокуляцией (34). Следовательно, усиление конкуренции между симбионтами может влиять на интенсивность внутрикорневой колонизации корней грибами АМ. Этим определяется интерес к изучению взаимного влияния симбионтов на растения.

Достаточно важным может быть взаимное влияние грибов АМ и ризобий в многокомпонентной системе, особенно при использованной нами последовательной инокуляции. Наши данные указывают на то, что для проявления позитивного влияния на растения важны не только комбинации определенных штаммов грибов и ризобий, но и схема проведения двойной инокуляции. В дальнейшем необходимо подобрать условия, в которых такая конкуренция будет уменышаться, а также оценить, не могут ли подобные изменения микоризной колонизации служить в роли маркера эффективности взаимодействия растений с грибами АМ при двойной инокуляции.

Таким образом, при последовательной инокуляции растений гороха сорта Frisson сначала грибами Rhizophagus irregularis BEG144, а затем ризобиями Rhizobium leguminosarum bv. viciae RCAM 1026 мы не наблюдали стимулирующего эффекта совместной инокуляции по сравнению с моноинокуляцией, что было показано на основании оценки индукции маркеров 
развития двух типов симбиоза, изучения микоризации корней и биометрических показателей растений. Это может указывать на наличие конкуренции микроорганизмов за нишу в растении или активацию системных механизмов, препятствующих усилению внутрикорневой колонизации симбионтами.

\section{ЛИТЕРАТУРА}

1. Lal R. Soils and sustainable agriculture: a review. In: Sustainable agriculture /E. Lichtfouse, M. Navarrete, P. Debaeke, S. Veronique, C. Alberola (eds.). Springer, 2009: 15-23 (doi: 10.1007/97890-481-2666-8_3).

2. Conway G.R., Barbier E.B. After the green revolution: sustainable agriculture for development. Routledge, London, 2013 (doi: 10.4324/9781315066820).

3. Mahanty T., Bhattacharjee S., Goswami M., Bhattacharyya P., Das B., Ghosh A., Tribedi P. Biofertilizers: a potential approach for sustainable agriculture development. Environmental Science and Pollution Research International, 2017, 24(4): 3315-3335 (doi: 10.1007/s11356-016-8104-0).

4. Bethlenfalvay G.J., Brown M.S., Franson R.L. Glycine-Glomus-Bradyrhizobium symbiosis: X. Relationships between leaf gas exchange and plant and soil water status in nodulated, mycorrhizal soybean under drought stress. Plant Physiology, 1990, 94(2): 723-728 (doi: 10.1104/pp.94.2.723).

5. Artursson V., Finlay R.D., Jansson J.K. Interactions between arbuscular mycorrhizal fungi and bacteria and their potential for stimulating plant growth. Environmental Microbiology, 2006, 8(1): 1-10 (doi: 10.1111/j.1462-2920.2005.00942.x).

6. Ballesteros-Almanza L., Altamirano-Hernandez J., Peca-Cabriales J.J., Santoyo G., SanchezYacez J.M., Valencia-Cantero E., Macias-Rodriguez L., Lopez-Bucio J., Cardenas-Navarro R., Farias-Rodriguez R. Effect of co-inoculation with mycorrhiza and rhizobia on the nodule trehalose content of different bean genotypes. The Open Microbiology Journal, 2010, 4(1): 83-92 (doi: 10.2174/11874285801004010083).

7. Bhattacharjee S., Dutta Sharma G. Effect of dual inoculation of arbuscular mycorrhiza and Rhizobium on the chlorophyll, nitrogen and phosphorus contents of pigeon pea (Cajanus cajan L.). Advances in Microbiology, 2012, 2(4): 561-564 (doi: 10.4236/aim.2012.24072).

8. Dilworth M.J. Dinitrogen fixation. Annual Review of Plant Physiology, 1974, 25(1): 81-114 (doi: 10.1146/annurev.pp.25.060174.000501).

9. Stewart W.D.P., Alexander G. Phosphorus availability and nitrogenase activity in aquatic bluegreen algae. Freshwater Biology, 1971, 1(4): 389-404 (doi: 10.1111/j.1365-2427.1971.tb01570.x).

10. Kondo M., Kobayashi M., Takahashi E. Effect of phosphorus and temperature on the growth and nitrogenase activity in Azolla-Anabaena association. Soil Science and Plant Nutrition, 1989, 35(2): 217-226 (doi: 10.1080/00380768.1989.10434754).

11. Crews T.E. Phosphorus regulation of nitrogen fixation in a traditional Mexican agroecosystem. Biogeochemistry, 1993, 21(3): 141-166 (doi: 10.1007/BF00001115).

12. Tajini F., Trabelsi M., Drevon J.J. Combined inoculation with Glomus intraradices and Rhizobium tropici CIAT899 increases phosphorus use efficiency for symbiotic nitrogen fixation in common bean (Phaseolus vulgaris L.). Saudi Journal of Biological Sciences, 2012, 19(2): 157-163 (doi: 10.1016/j.sjbs.2011.11.003).

13. Valdenegro M., Barea J.M., Azcón R. Influence of arbuscular-mycorrhizal fungi, Rhizobium meliloti strains and PGPR inoculation on the growth of Medicago arborea used as model legume for re-vegetation and biological reactivation in a semi-arid mediterranean area. Plant Growth Regulation, 2001, 34(2): 233-240 (doi: 10.1023/A:1013323529603).

14. Islam R., Ayanaba A., Sanders F.E. Response of cowpea (Vigna unguiculata) to inoculation with VA-mycorrhizal fungi and to rock phosphate fertilization in some unsterilized Nigerian soils. Plant and Soil, 1980, 54(1): 107-117 (doi: 10.1007/BF02182003).

15. Xavier L.J.C., Germida J.J. Selective interactions between arbuscular mycorrhizal fungi and Rhizobium leguminosarum bv. viceae enhance pea yield and nutrition. Biology and Fertility of Soils, 2003, 37(5): 261-267 (doi: 10.1007/s00374-003-0605-6).

16. Stancheva I., Geneva M., Zehirov G., Tsvetkova G., Hristozkova M., Georgiev G. Effects of combined inoculation of pea plants with arbuscular mycorrhizal fungi and Rhizobium on nodule formation and nitrogen fixing activity. General and Applied Plant Physiology, 2006, 1: 61-66.

17. Grunwald U., Nyamsuren O., Tamasloukht M., Lapopin L., Becker A., Mann P., GianinazziPearson V., Krajinski F., Franken P. Identification of mycorrhiza-regulated genes with arbuscule development-related expression profile. Plant Molecular Biology, 2004, 55(4): 553-566 (doi: 10.1007/s11103-004-1303-y).

18. Xie Z.P., Staehelin C., Vierheilig H., Wiemken A., Jabbouri S., Broughton W.J., Vogeli-Lange R., Boller T. Rhizobial nodulation factors stimulate mycorrhizal colonization of nodulating and nonnodulating soybeans. Plant Physiology, 1995, 108(4): 1519-1525 (doi: 10.1104/pp.108.4.1519).

19. Maillet F., Poinsot V., André O., Puech-Pagés V., Haouy A., Gueunier M., Cromer L., Giraudet D., Formey D., Niebel A., Martinez E.A., Driguez H., Becard G., Dénarié J. Fungal lipochitooligosaccharide symbiotic signals in arbuscular mycorrhiza. Nature, 2011, 469(7328): 58- 
64 (doi: 10.1038/nature09622).

20. Whipps J.M. Prospects and limitations for mycorrhizas in biocontrol of root pathogens. Canadian Journal of Botany, 2004, 82(8): 1198-1227 (doi: 10.1139/B04-082).

21. Volpiano C.G., Lisboa B.B., Granada C.E., José J.F.B.S., de Oliveira A.M.R., Beneduzi A., Perevalova Y., Passaglia L.M.P., Vargas L.K. Rhizobia for biological control of plant diseases. In: Microbiome in plant health and disease /V. Kumar, R. Prasad, M. Kumar, D. Choudhary (eds.). Springer, Singapore, 2019, 1(1): 315-336 (doi: 10.1007/978-981-13-8495-0_14).

22. Gao X., Lu X., Wu M., Zhang H., Pan R., Tian J., Li S., Liao H. Co-inoculation with rhizobia and AMF inhibited soybean red crown rot: From field study to plant defense-related gene expression analysis. PLoS ONE, 2012, 7(3): e33977 (doi: 10.1371/journal.pone.0033977).

23. Azcón R., Rubio R., Barea J.M. Selective interactions between different species of mycorrhizal fungi and Rhizobium meliloti strains, and their effects on growth, $\mathrm{N}_{2}$-fixation $\left({ }^{15} \mathrm{~N}\right)$ and nutrition of Medicago sativa L. New Phytologist, 1991, 117(3): 399-404 (doi: 10.1111/j.1469-8137.1991.tb00003.x).

24. Orosz L., Sváb Z., Kondorosi A., Sik T. Genetic studies on rhizobiophage 16-3. I. Genes and functions on the chromosome. Molecular and General Genetics MGG, 1973, 125(4): 341-350 (doi: 10.1007/BF00276589).

25. Shtark O.Y., Sulima A.S., Zhernakov A.I., Kliukova M.S., Fedorina J. V., Pinaev A.G., Kryukov A.A., Akhtemova G.A., Tikhonovich I.A., Zhukov V.A. Arbuscular mycorrhiza development in pea (Pisum sativum L.) mutants impaired in five early nodulation genes including putative orthologs of NSP1 and NSP2. Symbiosis, 2016, 68(1-3): 129-144 (doi: 10.1007/s13199-016-0382-2).

26. Kirienko A.N., Porozov Y.B., Malkov N.V., Akhtemova G.A., Le Signor C., Thompson R., Saffray C., Dalmais M., Bendahmane A., Tikhonovich I.A., Dolgikh E.A. Role of a receptor-like kinase $\mathrm{K}_{1}$ in pea Rhizobium symbiosis development. Planta, 2018, 248(5): 1101-1120 (doi: 10.1007/s00425-018-2944-4).

27. Leppyanen I.V., Shakhnazarova V.Y., Shtark O.Y., Vishnevskaya N.A., Tikhonovich I.A., Dolgikh E.A. Receptor-like kinase LYK9 in Pisum sativum L. is the CERK1-like receptor that controls both plant immunity and AM symbiosis development. International Journal of Molecular Sciences, 2017, 19(1): 8 (doi: 10.3390/ijms19010008).

28. Jin Y., Liu H., Luo D., Yu N., Dong W., Wang C., Zhang X., Dai H., Yang J., Wang, E. DELLA proteins are common components of symbiotic rhizobial and mycorrhizal signalling pathways. Nature Communications, 2016, 7: 12433 (doi: 10.1038/ncomms12433).

29. Fonouni-Farde C., Tan S., Baudin M., Brault M., Wen J., Mysore K.S., Niebel A., Frugier F., Diet A. DELLA-mediated gibberellin signaling regulates Nod factor signalling and rhizobial infection. Nature Communications, 2016, 7: 12636 (doi: 10.1038/ncomms12636).

30. Scheres B., van Engelen F., van der Knaap E., van de Wiel C., van Kammen A., Bisseling T. Sequential induction of nodulin gene expression in the developing pea nodule. The Plant Cell, 1990, 2(8): 687-700 (doi: 10.1105/tpc.2.8.687).

31. Dolgikh E.A., Leppyanen I. V., Osipova M.A., Savelyeva N.V., Borisov A.Y., Tsyganov V.E., Geurts R., Tikhonovich I.A. Genetic dissection of Rhizobium-induced infection and nodule organogenesis in pea based on ENOD12A and ENOD5 expression analysis. Plant Biology, 2011, 13(2): 285-296 (doi: 10.1111/j.1438-8677.2010.00372.x).

32. Zhukov V., Radutoiu S., Madsen L.H., Rychagova T., Ovchinnikova E., Borisov A., Tikhonovich I., Stougaard J. The Pea Sym 37 receptor kinase gene controls infection-thread initiation and nodule development. Molecular Plant-Microbe Interactions, 2008, 21(12): 1600-1608 (doi: 10.1094/MPMI-21-12-1600).

33. Niwa R., Koyama T., Sato T., Adachi K., Tawaraya K., Sato S., Hirakawa H., Yoshida S., Ezawa T. Dissection of niche competition between introduced and indigenous arbuscular mycorrhizal fungi with respect to soybean yield responses. Scientific Reports, 2018, 8: 7419 (doi: 10.1038/s41598-018-25701-4).

34. Engelmoer D.J., Behm J.E., Toby Kiers E. Intense competition between arbuscular mycorrhizal mutualists in an in vitro root microbiome negatively affects total fungal abundance. Molecular Ecology, 2014, 23(6): 1584-1593 (doi: 10.1111/mec.12451).

\section{ФГБНУ Всероссийский НИИ сельскохозяйственной микробиологии, \\ Поступила в редакцию 18 ноября 2020 года}

196608 Россия, г. Санкт-Петербург-Пушкин, ш. Подбельского, 3,

e-mail: irina leppyanen@mail.ru,oshtark@yandex.ru,dobbi85@list.ru, andy-piter2007@mail.ru, kivanova@arriam.ru,t_serova@rambler.ru, dol2helen@yahoo.com $₫$

\section{ANALYSIS OF THE EFFECTS OF JOINT INOCULATION BY ARBUSCULAR MYCORRHIZAL FUNGI AND RHIZOBIA}




\section{I.V. Leppyanen, O.Y. Shtark, O.A. Pavlova, A.D. Bovin, K.A. Ivanova, T.S. Serova, E.A. Dolgikh $\bowtie$}

All-Russian Research Institute for Agricultural Microbiology, Federal Agency for Scientific Organizations, 3, sh. Podbel'skogo, St. Petersburg, 196608 Russia, e-mail irina_leppyanen@mail.ru, oshtark@yandex.ru, dobbi85@list.ru, andy-piter2007@mail.ru, kivanova@arriam.ru, t_serova@rambler.ru, dol2helen@yahoo.com (corresponding author $\bowtie$ ) ORCID:

Leppyanen I.V. orcid.org/0000-0002-2158-0855

Shtark O.Y. orcid.org/0000-0002-3656-4559

Pavlova O.A. orcid.org/0000-0003-0528-5618

Bovin A.D. orcid.org/0000-0003-4061-435X

The authors declare no conflict of interests

Acknowledgements:

Supported financially by the Russian Science Foundation (grant No. 17-76-30016)

Received November 18, 2020

Ivanova K.A. orcid.org/0000-0003-4915-4126

Serova T.S. orcid.org/0000-0003-4784-1675

Dolgikh E.A. orcid.org/0000-0002-5375-0943

\section{Abstract}

doi: $10.15389 /$ agrobiology.2021.3.475eng

Co-inoculation of plants with arbuscular mycorrhizal (AM) fungi and nitrogen-fixing bacteria of the order Rhizobiales (rhizobia) can have a stimulating effect on plant growth and development. This influence can be considered as the synergistic effect of two microorganisms on a plant in a multicomponent system and as the result of the mutual influence of microorganisms on each other. However, the mechanisms underlying the mutual influence of microorganisms remain insufficiently understood. In the presented work, it was shown for the first time that in the case of joint inoculation of pea plants with fungi of arbuscular mycorrhiza and rhizobia, the method of introduction microorganisms may be important. The results may indicate the presence of competition of microorganisms for a niche in the plant during sequential inoculation. The purpose of our research was to study the possibility of selection of the effective combinations of AM and rhizobia strains for inoculation of such important agricultural crop as Pisum sativum L. as well as estimation of influence on the productivity of plants. In this work, we analyzed the effects of joint inoculation of pea plants Pisum sativum L. with the fungus Rhizophagus irregularis BEG144 and the rhizobial strain $R$. leguminosarum bv. viciae RCAM 1026. For this purpose, the level of induction of markers development of two types of symbiosis, the degree of root mycorrhization were assessed, as well as the biometric parameters of plants. The research was performed using pea seedlings of the cultivar Frisson grown under sterile conditions. The isolate of the fungus Rhizophagus irregularis BEG144 was used for inoculation. An inoculum was obtained from the mycorrhized roots of Plecthrantus australis. The inoculum was introduced into a moisture substrate before planting the pea seedlings. The scheme of sequential inoculation was used, according to which pea plants were first inoculated with AM fungi $R$. irregularis BEG144 and 7 days after cultivation, the rhizobial strain Rhizobium leguminosarum bv. viciae RCAM 1026 were introduced into the system. The experimental scheme included the following options: without inoculation (control), $R$. leguminosarum (Rlv), $R$. irregularis (AM), $R$. irregularis $+R$. leguminosarum (AM + Rlv). 9 and 21 days after planting ( 2 and 14 days after bacterial inoculation), the material was collected to analyze the expression of genes - markers of the legume-rhizobial symbiosis development. On day 21 after planting, the plants were collected in order to determine their biometric parameters, as well as the markers of the symbiosis development. The lateral roots of the plants were cut off and frozen in liquid nitrogen. After isolation of the total RNA, cDNA was synthesized on the RNA template using reverse transcriptase using oligo(dT) primers. For the analysis, quantitative PCR combined with reverse transcription (RT-PCR) was performed (a CFX96 Real-Time instrument, «Bio-Rad Laboratories», USA). The total weight of plants and the weight of the root system significantly increased in case of monoinoculation with rhizobia, monoinoculation with AM fungi, as well as joint inoculation, compared with the control variant. However, no significant differences in these biometric parameters between the variant with monoinoculation with rhizobia or AM fungi and double inoculation were found. Probably, upon inoculation with several endosymbionts, competition arose between them at the stage of penetration into the plant, which led to a decrease in the intensity of plant infection with rhizobia. This was evidenced by the absence of additional stimulation of the Enod 5 and Sym 37 gene expression during double inoculation, which are activated in the plant during the development of rhizobial infection. Upon double inoculation, we also did not reveal additional stimulation of the expression of marker genes of symbiosis with AM fungi - PT4, TI, RAMI and DELLA3. This correlated with the absence of significant differences in all biometric parameters between the variant with monoinoculation with rhizobia or AM fungi and double inoculation, which does not allow us to conclude about the positive effect of double inoculation on the growth and development of pea plants under the conditions of this experiment. The results of data analysis using the experimental scheme used may indicate the presence of competition of microorganisms for a niche in the plant, leading to a decrease in intra-root mycorrhizal colonization and the level of induction of markers that are activated during the development of rhizobial infection.

Keywords: plant-microbe interactions, rhizosphere, symbiosis, arbuscular mycorrhiza, inoculation, rhizobia, Rhizophagus irregularis, gene expression, Pisum sativum. 